\title{
Theoretical Research on College Students' Creative Quality Education
}

\author{
Xiujuan Liu ${ }^{\text {a, }}$, Xin Bai ${ }^{\text {a }}$, Wenhui Chen ${ }^{\text {a }}$, Chunguang Wang ${ }^{a}$ \\ Beijing Institute of Technology, Zhuhai, School of Aviation, Zhuhai, 519088, China \\ aemail:723704537@qq.com \\ "corresponding author
}

Keywords: College students; Creativity; Quality education

\begin{abstract}
Based on the development of modern society and the development of higher education, this paper analyzes the basic basis for carrying out creative quality education for college students from the perspective of objective and realistic needs, and discusses the training objectives and educational principles of creative quality education for college students.
\end{abstract}

\section{Introduction}

College students' creative quality education is an important part of the comprehensive quality training of college students and one of the important factors for the overall development of college students. In recent years, people have received more and more attention and attention. Cultivating high-quality talents with creative qualities is not only an urgent need for higher education in the new era, but also an important indicator for measuring the quality of college education. In order to adapt to the new situation, we should take the "scientific development concept" and "modern education concept" as the guide, constantly update the concept of education, and deeply study the theory of creative quality education for college students.

\section{The Basic for Vigorously Carrying out Creative Quality Education for College Students}

\subsection{Creative Quality Education is the Objective Need of Modern Social Development.}

Today's society has entered the era of knowledge economy, and creative quality has become the source of power for the prosperity of the country and the nation. It is of great significance to carry out creative quality education for college students [1].

First, it can stimulate the creative motive of college students, optimize the creation of individuality, and enable students to use lofty ideals and correct outlook on life as the driving force to overcome all difficulties and maintain the firmness of behavior.

Second, it can strengthen the self-creation consciousness of college students. Self-creation consciousness is a person's understanding of the relationship between himself and the outside world, including not only his own understanding of his creative ability, but also the active transformation of his own creative potential. The purpose of strengthening college students' self-creation consciousness is to enhance college students' self-worth and self-efficacy to adapt to the objective needs of fierce competition, accelerated life rhythm and increasingly complex social environment.

Third, it can enhance the ability of college students to think creatively. The role of creative thinking can predict the future, select the target, and win the initiative. It can make it consciously get rid of the traditional mode of thinking according to objective requirements in study, life and work. Various difficult and complex scenarios under the conditions of the knowledge economy may occur frequently. College students can adapt to society and adapt to life only if they have good creative qualities.

Fourth, it can enhance the ability of college students to coordinate and cooperate with each other. In modern society, the explosion of knowledge and the speed of renewal have grown exponentially. Whether it is academic, scientific research, or project work, it is impossible to meet the needs of 
modern society by relying on one's own efforts. Only those who understand each other and have a spirit of cooperation can succeed [2]. Creative quality education is an objective need for the development of modern society. It is an indisputable fact.

\subsection{Creative Quality Education is the Practical Need of Higher Education.}

Western educators believe that those who have received higher education, if they have carried out creative quality education in their future professional life, tend to be flexible in their programs and creative in their composition; but if they have not done creative quality education, even if they have If you are highly educated, you will be more mediocre and less creative. This is because in the creative thinking activities, divergent thinking dominates the scientific thinking method. People who have been educated in creative quality can often use scientific thinking methods, use divergent thinking, and work creatively. Those who have not been educated in creative quality will have relatively weak scientific thinking methods, especially imaginative thinking and divergent thinking skills. They often lack the good habit of asking a few more "why", and it is even more impossible to do the same. Insufficient creativity at work. Practice shows that creative quality education is the practical need of higher education.

\subsection{Creative Quality Education is the Theoretical Support to Improve the Creative Quality of College Students.}

In China, creative quality education is still a "sunrise industry", and the problem of creative quality education for college students is more prominent. The main reason is that the understanding of college students' creative quality education is not in place, the conditions for college students' creative quality education are still not perfect, and there is a lack of systematic research on the creative quality education of college students. In recent years, college students' creative quality education has begun to receive attention. Some colleges have discussed and studied the creative quality education of college students, and have achieved positive results, which have improved the creative quality of college students to varying degrees, but the quality requirements of college students [3]. There is still a big gap. Creative quality education can not only provide motivation for the sustainable development of college students, but also effectively improve the overall quality of college students. The reality is that the foundation for the cultivation of creative quality of college students is very weak. As the theoretical support of creative quality education in colleges and universities, it is necessary to establish the theoretical system and practical system of creative quality education for college students.

\section{The Training Objectives and Educational Principles of College Students' creative Quality Education}

\subsection{Training Objectives.}

The goal of college students' creative quality education is an important part of the overall training goal of college students, and it is the starting point and destination of college students' creative quality education. The goal of college students' creative quality education should be based on the purpose of higher education, in accordance with the quality requirements of modern society, to cultivate the creative qualities of college students and improve their comprehensive ability. The creative quality education of college students should not only meet the actual needs of the social transformation period, but also take into account the needs of the development of modern society in the era of knowledge economy. The creative quality education of college students is to train college students to have the creative qualities that meet the needs of the knowledge economy era and the modern society: perfect creative personality, unique creative thinking quality, excellent creative will quality and excellent creative adaptability (all kinds of difficult and complicated environments). The brave and tenacious and creative enthusiasm, the ability to create, the good coordination and the spirit of cooperation. Its purpose is to make higher education more suitable for the needs of modernization, adapt to the needs of modern social development, and adapt to the needs of students' 
sustainable development.

\subsection{Educational Principles.}

Creative quality education is the basic way to achieve training objectives and an important part of teaching reform [4]. The basic goal of creative quality education is to cultivate college students' creative qualities that meet the needs of the knowledge economy era and modern society. Therefore, the creative quality education of college students must establish the following principles.

First, the principle of inspiration. The enlightening principle means that in the process of creative quality education, we must always pay attention to cultivating the positive adaptability, harmonious development and active creative spirit of college students, establish a correct world outlook, outlook on life and values, and become qualified talents needed for the rejuvenation of the Chinese nation. From the content of creative quality education for college students, it is necessary to reflect the essential characteristics and characteristics of the times of socialist creation and development. It is progressive, and it is necessary to cultivate students' good creative qualities and promote the creativity of college students with the world outlook, outlook on life and values of students. Organically combined, college students can learn to master correct thinking methods, establish positive thinking patterns, develop noble moral sentiments, develop excellent creative qualities, and unwittingly receive dialectical materialism science while accepting creative quality education. Enlightenment of ideas and creation of ideal education.

Second, the principle of full-staff. College students' creative quality education should be open to all college students. The well-known educator Mr. Tao Xingzhi once pointed out that everywhere is the place of creation. Every day is the time of creation. Everyone is the person of creation, and everything is the matter of creation. The survey shows that more than half of college students lack creativity and creativity. If these students do not carry out creative quality education, they are likely to affect their growth and development. If they can get timely creative quality education, the situation will be greatly improved. Therefore, facing all students and paying attention to individual students should be a basic requirement for creative quality education.

Third, the principle of subjectivity. The purpose of creative quality education is to cultivate the good creative qualities of college students. All educational methods must be implemented on the students. All educational effects must also be reflected in the students. Apart from the active participation and conscious efforts of the students, the efforts of creative quality education will be half the effort. Therefore, we must fully understand the status and role of the student subject, and fully understand the effectiveness of the creative quality education is based on the enthusiasm and participation of the student subject. Educators should do their utmost to fully understand the students. In the process of education, students should be the starting point and destination, and provide and create conditions as much as possible to make students become the "protagonists" in the process of creative quality education.

Fourth, the principle of development. Development is the main content of college students' creative quality education. All work in creative quality education should be centered on "promoting development". We must focus on the process of actively guiding students' learning, life, interpersonal communication and personality development, cultivating college students' good creative qualities and promoting college students. Develop in a comprehensive and harmonious manner. Educators should look at students with a developmental perspective, believe in students' creative will and potential, and be optimistic about the future of students. At the same time, educators should be good at stimulating college students' creative motives, creating enthusiasm, creating will and creating morality through curriculum reform, classroom teaching, scientific and technological innovation, evaluation activities, etc., so that creative quality education truly becomes the inevitable process and product of college students' "development"[5].

Fifth, the principle of synergy. The creative quality education of college students is part of the school education work. It cannot be carried out in isolation, and it cannot be separated from the various education and teaching work of the school. From the perspective of the education system, creative quality education should be infiltrated into all kinds of education, so that the requirements 
of creative quality education are combined with the educational requirements of moral, intellectual, physical and aesthetic education; from the specific curriculum, creative quality education should penetrate In the teaching of various subjects; from the perspective of school work, creative quality education should be included in education, teaching, and school management; from the perspective of student activities, creative quality education should be integrated into in-class learning, extracurricular activities, and party and group activities. In terms of the division of faculty and staff in schools, full-time creative quality education teachers and other teachers should cooperate with each other to jointly undertake the task of students' creative quality education. In short, it is necessary to work in a coordinated manner in a multi-angle, multi-level, and multi-faceted manner, and the creative quality education of college students can receive good results.

\section{Conclusion}

Studying the mode and method of creative quality education for college students is to deepen the education and teaching reform in colleges and universities in the new era, improve the quality of education and teaching, adhere to the virtues of the people, promote and strengthen the education of the socialist core value system, improve the excellent traditional Chinese culture education, and build love learning. The effective form and long-term mechanism of loving labor and loving the motherland have important implications for enhancing the social responsibility, innovation and practical ability of college students.

\section{References}

[1] Shibang Zhou. How to cultivate students' creative thinking in mathematics teaching, quality education forum [J].2015(1):100

[2] Junmin Liu. On the Cultivation of Creative Thinking, Jiangxi Education and Research [J]. 2005(6)17

[3] Yimei Ren. On College Students' Creative Thinking and Innovation Ability Cultivation, Education and Occupation [J]. 2006(8)143

[4] Educational technology papers, the ratio of entrepreneurial education models of college students at home and abroad, http://www.sofabiao.com/fblw/jiaoyu/jishu/26496.html

[5] Wei Zhang. Reflections on College Students' Innovation and Entrepreneurship Education, www.hexinqk.com 